\title{
The Dynamics of Spatial Structure and Spatial Pattern Changes at the Fringe Area of Makassar City
}

\author{
Batara Surya
}

Received: 3001 2015 / Accepted: 02022015 / Published online: 30062015

๑ 2015 Faculty of Geography UGM and The Indonesian Geographers Association

\begin{abstract}
The study is conducted at the fringe area of Makassar City by analyzing dynamics of spatial structure and spatial pattern changes at the fringe area of Makassar City. It applies quantitative and qualitative approaches (mixed method). Data is acquired from some sources and informants living at the fringe area of Makassar City. Spatial utilization shift and development of transport infrastructure, especially for main road corridor connecting down town of Makassar City and fringe area, affect significantly spatial structure and spatial pattern changes at the fringe area of Makassar City. Dynamics of spatial structure and spatial pattern changes contributes changes of resident mobility; while, development tendency of the existing spatial and land use is no longer determined based on productivity, but it is valued by functions of space and land at the fringe are of Makassar City.
\end{abstract}

Keywords: Changes in Land Use, Changes in Structure of Space, And Pattern Change Space, Fringe Area

\begin{abstract}
Abstrak Penelitian ini dilakukan pada kawasan pinggiran Kota Makassar dengan menganalisis dinamika perubahan struktur ruang dan pola ruang kawasan pinggiran Kota Makassar, menggunakan pendekatan kuantitatif dan kualitatif (mixed method). Data diperoleh dari beberapa sumber dan informan yang mendiami kawasan pinggiran Kota Makassar. Pergeseran pemanfaatan ruang dan perkembangan prasarana transportasi khususnya pada koridor jalan utama yang menghubungkan pusat Kota Makassar terhadap kawasan pinggiran, berpengaruh secara signifikan terhadap perubahan struktur ruang dan pola ruang kawasan pinggiran Kota Makasar. Dinamika perubahan struktur ruang dan pola ruang berkonstribusi terhadap perubahan mobilitas pergerakan penduduk, dan kecenderungan perkembangan pemanfaatan ruang dan lahan yang ada tidak lagi dinilai berdasarkan produktivitasnya akan tetapi dinilai berdasarnya fungsinya pada kawasan pinggiran Kota Makassar.
\end{abstract}

Kata kunci: Perubahan Pemanfaatan Ruang, Perubahan Struktur Ruang, Dan Perubahan Pola Ruang, Kawasan Pinggiran.

\section{Introduction}

Activity function shift at the down town of Makassar City is identified as the consequence of modernization and globalization factors, while by the time urbanization occurs, it directly causes land use conversion which occurs intensively enough at the fringe area of Makassar City. This condition is marked by expansion of strategic economic activities and other social functions. It implies to the occurrence of continuous transformation process at the fringe area, and also it makes spatial physical appearance of this area change. Other implication is suburbanization which occurs fairly significant at the fringe area of Makassar City. Observable direct impact is spatial function shift and morphological changes at the fringe area of Makassar Area.

In general, to understand development process of Makassar City, there are two principles: First, Makassar City is designated as the development center for

Batara Surya

Urban Regional Planing University of “45” Makassar, Indonesia Email: bataraciptaperdana@yahoo.co.id
Eastern Indonesia Zone (KTI) and at the same time, it also becomes national and regional activity center concerned with its position as the provincial capital of South Sulawesi Second, reposition of Makassar as global city refers to a fact where rapid growth rate isshown by urban economic activity centers and urbanization world wide heading to modernization of a city; accordingly, it indicates that modernization of city has also happened in Makassar. In the growth process of Makassar, it is not only affected by activities taking place there in, but it is also affected by external factors. Regarding development of Makassar City in which the city becomes activity center at national and regional scale, it will finally create intercity linkage pattern. Afterwards, this linkage willform planological concentration and urban services center system in Mamminasata Metropolitan.

Formation process of spatial linkage pattern at the fringe area of Makassar City makes physical, social and economic interaction among surrounding cities of Makassar work quite intensive, hence it forms movement of persons, goods, fund, services 
and innovation via urban transport infrastructure network. These flows and networks, then, build a linkage of intercity economic system in Mamminasata Metropolitan. Further process repositions Makassar City as a core city and accumulation center for strategic socio economic activity at national and regional scale.

Revolutionary spatial physical changes through spatial functions shift at the fringe area of Makassar City are not only driven by urbanization factor, but it also relates to shift of means of production toward reproduction of and production of space in representational manner. Consequently, it changes Makassar face into modern city. This reality is relevant to theoretical conceptualization of Lefebvre (in Ritzer, 2008) that representation of elite space dominates spatial practice and representational space. It means that production of space, which is representational performed by elites, triggers dynamics of spatial structure and spatial pattern changes at the fringe area of Makassar City.

Considering on the process, it is assumed that dynamics of spatial structure and spatial pattern changes at the fringe area of Makassar City has two affecting factors, i.e.(a) spatial development process in centrifugal manner and (b) spatial development in centripetal manner. The reality conforms to theoretical conceptualization of Yunus [2008] stating that spatial development process horizontally becomes determination of urban area expansion and building density at the urban fringe area. Thus, spatial function shift of Makassar City center heading to fringe area is a sort of spatial expansion process which occurs horizontally by occupying empty spaces. This process, then, is justified as accelerator for spatial structure and spatial pattern changes at the fringe area of Makassar City. Spatial function shift heading to the fringe area of Makassar City is marked by land use conversion and development of new activity functions, for example functions of residential area, trade, industry, tourism, education, health, office, services and other commercial functions [Soetomo, S. 2009].

Early condition before development at the fringe area of Makassar City was present, economic value of the land was low. After construction was carried out by the developer, the land is not only utilized to build shopping center (Mall and shopping complex), but also to build elite residential area along with adequate, complete and modern means and infrastructure. More over, developer also prepares Mature Land Plot (Kaveling Tanah Matang or KTI); consequently, the fringe area of Makassar City transforms into new location for residential area and new economic center. The reality is in line with theoretical conceptualization developed by Yunus [2008] that there aresix factors affecting urban fringe area development, they area: First, accessibility factor. Physical accessibility changes at the fringe area of Makassar City are shown by development of transport infrastructure which makes connection and accessibility therein increase. Second, factor of public services; this attractive factor stimulates resident mobility and replaces urban functions at the fringe area of Makassar City.Third, characteristics of land; it takes the role as stimulating factor affecting the height of new functions development and expansion. Fourth, characteristics of land property; in principal, it refers to spatial development pattern at a place regarding on development intensity and acceleration. Fifth, presence of regulation regulating spatial zoning plan; it is one of factors affecting spatial physical changes intensity at the fringe area of Makassar City, and sixth, factor of developer initiative; it has very significant influence in directing spatial physical development at the fringe area of Makassar Area. These six factors are justified as the determining factor in dynamics of spatial structure and spatial pattern changes, function of agglomeration and dis agglomeration at the fringe area of Makassar City.

\section{The Methods}

Research site is in the fringe area of Makassar City (Figure 1). It is carried out on November, 2011 to August, 2013. Applied approach is case study. Case study characteristics aim at understanding background or phenomenon as the consequence of dynamics of spatial structure and spatial pattern changes at the fringe area of Makassar City.

Applied data analysis method is quantitativequalitative method (mixing methods) from Denzin and Lincoln [2009]. Philosophical reason in combining these two approaches are: (1) triangulation logic; in this matter, qualitative research finding is rechecked by quantitative research, and vice versa in order to strengthen the findings validity, (2) quantitative and qualitative research are combined to give a general over view, (3) quantitative research is applied to structural characteristics of social life, and qualitative research takes subject's quality as starting point, so these two approaches are attended collectively to execute the study, (4) quantitative research is applied in analyzing relationship of inter-alterations, qualitative research is applied to assist in harmonizing factors underlying constructed relationship, (5) quantitative approach is applied to reveal structural characteristics of social life in large-scale size, while qualitative approach tends to reach behavioral in small-scale size, so researcher makes an effort to reveal these two levels, so quantitative and qualitative guides are applied collectively, and (6) in order to obtain data of the two different realities, it needs combination of the two approaches (quantitative and qualitative).

\section{Result and Discussion}

Developmental dynamics at the fringe area of Makassar City is affected by area expansion, specifically expansion effect of Mamminasata Metropolitan. Regarding Mamminasata Metropolitan expansion, Makassar City is designated as core city 


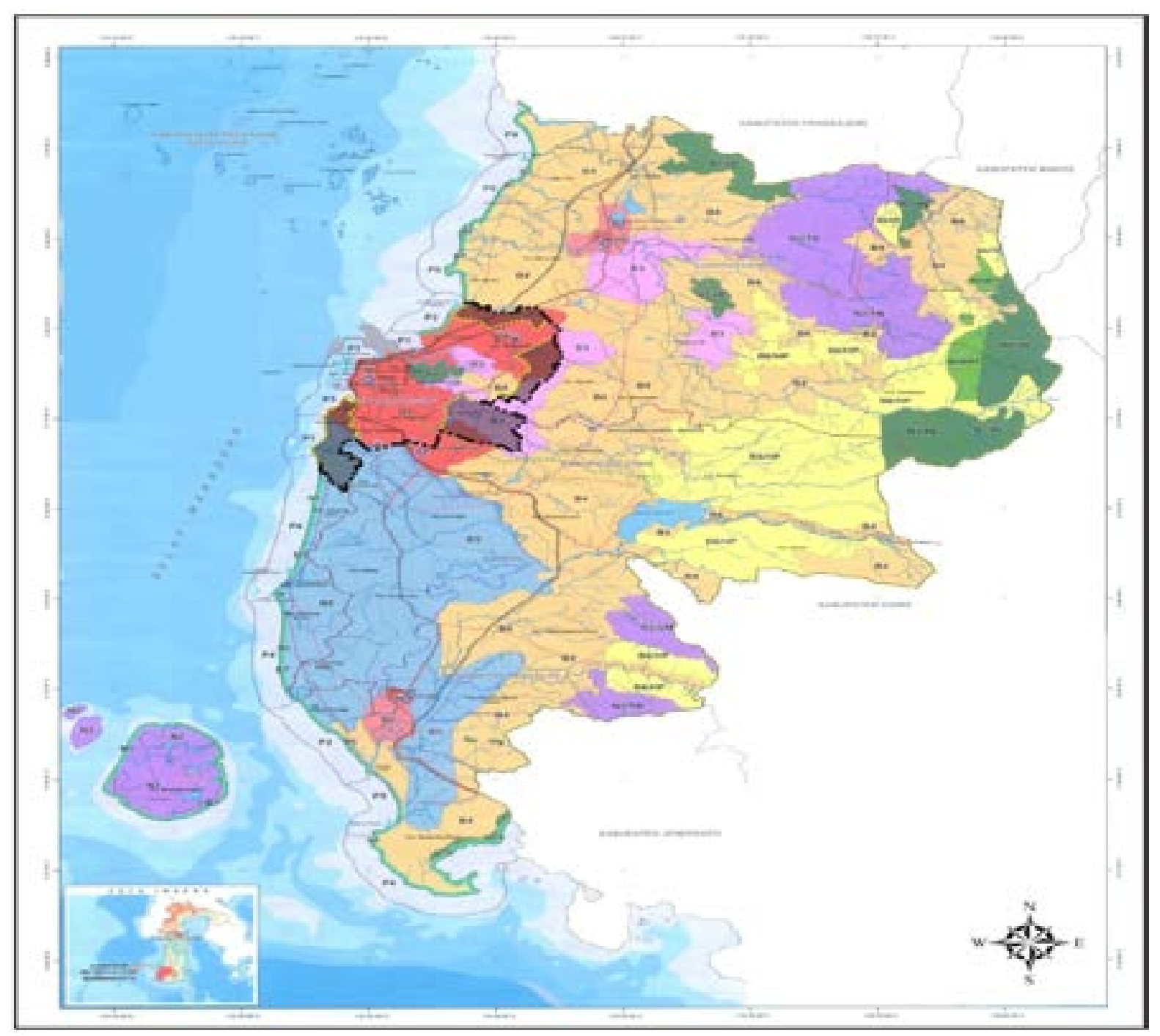

Figure 1. Location Map at Fringe Area of Makassar City as Object of the Study

over surrounding cities like Sungguminasa, Takalar and Maros Cities. This designation, then, affects accelerated growth at the fringe area of Makassar City. It affects significantly urban spatial utilization shift at Mamminasata Metropolitan.

Spatial utilization shift at the fringe area of Makassar City is marked by intensive land use conversion, thus it changes morphological appearance at this area. The findings show that spatial utilization shift at Makassar City is proved by presence of dominant new functions, for example functions of industry, education, trade, transport services and residential function. Growth of functions at the fringe area of Makassar City indicates that land use conversion, based on its intensity, is highly determined by new residential functions at a large scale. Accordingly, residential function has a very significant influence on the land use conversion, and it associates positively to urbanization process happened over time. Dominantly, migrants live at this fringe areaas the place to live.

Process of spatial utilization shift at the fringe area of Makassar City affects resident orientation change on activity and their operated business. During year period from 2000-2002 and 2003-2011, growth at the fringe area of Makassar City is marked by rapid accelerated growth, and of course, it is shadowed by population growth. Existing land use conversion directly affects spatial pattern changes and it reduces size of agricultural land and rearing pond. It is shown by the height of land sales and purchases. Consequently, since twoyear periods, agricultural and fisheries business are no longer became dominant business as main livelihood of the residents. This phenomenon implies that resident orientation on livelihood changes a lot and it depends on spatial physical change and spatial function shift at the fringe area of Makassar City.

Tabel 1, this fact illustrates that resident orientation at the fringe area of Makassar City on livelihood has shifted. Three resident orientation on livelihood after the occurrence of spatial physical changes and spatial function shift are (1) relative small number on agricultural business, (2) informal sector business, and (3) formal sector business, especially for those who have specific education and skill (people working in 
Table 1. Resident Orientation Change on Livelihood in 2003-2011

\begin{tabular}{lrrrrr}
\hline \multicolumn{1}{c}{ Livelihoods } & $\begin{array}{c}\text { The number of } \\
\text { heads of } \\
\text { household in } \\
\text { 2003 (Soul) }\end{array}$ & \multicolumn{3}{c}{$\begin{array}{c}\text { 2011 (Soul) } \\
\text { of heads of }\end{array}$} & Remarks \\
\hline Farmers & 2.036 & 68,25 & 112 & 3,07 & decreased \\
Fishermen & 621 & 20,82 & 50 & 1,36 & decreased \\
Labour & 38 & 1,27 & 2.100 & 57,50 & increased \\
Government Employees & 6 & 0,20 & 22 & 0,60 & increased \\
Armi & - & - & 3 & 0,08 & increased \\
Handyman & 231 & 7,74 & 1.000 & 27,38 & increased \\
Ojek & - & - & 50 & 1,37 & increased \\
Roving Trader & 12 & 0,40 & 123 & 3,37 & increased \\
Shop / Small & 11 & 0,36 & 24 & 0,66 & increased \\
Others (Odd) & 28 & 0,94 & 168 & 4,60 & increased \\
Total & 2.983 & 100 & 3.652 & 100 & \\
\hline
\end{tabular}

Table 2. Resident Business at the Urban Fringe Area of Makassar City in 2003-2011

\begin{tabular}{lrrrrl}
\hline Business Sector & $\begin{array}{l}\text { Business } \\
\text { Sector 2003\% }\end{array}$ & & $\begin{array}{l}\text { Business } \\
\text { Sector 2011\% }\end{array}$ & Remarks \\
& 96 & 14,79 & 36 & 2,88 & decreased \\
\hline Agriculture & - & - & 10 & 0,80 & increased \\
Industry & 137 & 21,11 & 143 & 11,42 & increased \\
$\begin{array}{l}\text { Building Con- } \\
\text { struction }\end{array}$ & & & & & \\
Trade & 406 & 62,56 & 977 & 78,04 & increased \\
Transportation & 10 & 1,54 & 86 & 6,87 & increased \\
Total & 649 & 100 & 1.252 & 100 & \\
\hline
\end{tabular}

commercial business).

The table 2 portrays phenomenon in 2003 where $14.79 \%$ of residents work inagricultural sector and in the end of $2011,2.88 \%$ of working age residents at the fringe area of Makassar City work in agricultural sector. When it was 2003, industrial activities have not been carried out a lot, but in the end of 2011, job vacancy in this business in creases by $0.8 \%$. In $2011,11.42 \%$ of working age residents works at building construction. The largest percentage of business sector in the end of 2011 is achieved by trade sector. It reaches $78.04 \%$ and dominantly, trading businesses are carried out by migrants where trading location is means of commerce is built by developer. The meaning there of, from the time when rapid spatial physical changes at the fringe area of Makassar City take place, most of residents change their jobs into construction worker, small food stall, green vegetable peddler, villa and lodging rentals, and Mall employee, staffs of tourist resort or recreation, or handyman. A small portion of residents are working in transport sector (driver of a public transport or an ojék/hired motorcycle). It is just a small quantity of residents who make their life dependent on agricultural business and home industry compared to other sector. Those who keep working in this sector are agricultural land owners where the land they possessed is relative narrow. Some other residents utilize empty land or other farm land which has not been utilized by developer for construction.

Spatial utilization shift at the fringe area of Makassar City not only causes intensive land use conversion, but it also changes appearance and morphology at the fringe area of Makassar City at small and large scale. Therefore, it can be concluded that accelerated growth which tends to be revolutionary has modified appearance of the fringe area of Makassar City from productive agricultural functions into urban complexity, and it also encourages orientation changes of resident activity to be industrial city. The findings show that urban commercial functions grow dominantly through out main road corridor which is shown by the presence of shopping centers and new shopping complexes. Whereas, new residential area, especially which was built by developer, is designed in varied residential clusters. Houses built therein, commonly, have different design and developed architectural model; therefore, it 
illustrates different resident's economic capacity to meet residential needs [Forbes, K.D. 1983].

In another aspect, spatial utilization shift at the fringe area of Makassar City will finallycause complex spatial expression. Prominent spatial expression is observable in mainservice centers at the fringe area of Makassar City [Nas, P. J.M. 2005].

Spatial utilization shift at the fringe area of Makassar City, based on the findings, indicates that presence of new developed functions contributes positively to formation of new social structure there in. Accordingly, social structure changes are not only affecting social formation changes, but they are also creating social stratum, social status, and social classes. They also streng then capitalism in dominating reproduction of space at the fringe area of Makassar City. There fore, it can be concluded that orientation change on resident livelihood at this area is affected by three main factors: (1) social system development in society is in unrepeated system condition, (2) further condition of the system reflects a higher level; in this case, there is structure differentiation in crease, i.e. economic output rise, economic advancement and population growth, and (3) development which is triggered by tendency in the system; in this matter, population growth associates with population density and internal contradiction by formulating new life at the fringe area of Makassar City.

Important point in spatial analysis developed by Levebvre (1972/1971) states thatspatial practice will shift from means of production to reproduction of space, so it makes spatial structure and spatial pattern change. Accordingly, phenomenon found in this proceeding process at the fringe area of Makassar City associates positively with spatial function shift from means of production to reproduction of space. In many cases, space is reproduced by capitalist system, so it creates class structure in economic system. Conclusion may be made that spatial function shift at the fringe area of Makassar City has significant influence on production of space in representational manner and social structure changes in the society heading to the more complex social structure.

Development dynamics at the fringe area of Makassar City, based on the findings, indicate that intensive land use conversion associates positively with formation of new spatial structure at this area. Formed spatial structure at fringe area contributes to social structure changes in the society because it is bridged by presence of new functions and transportation system changes at the fringe area of Makassar City. Centrifugal spatial physical development which occurs length wise expands region of Makassar City, so it enlarges urban area. Accordingly, to the length wise direction where development is given will become constructed area (Figure 2). This length wise track is the road corridor going to the direction of Gowa Regency, Takalar Regency and Maros Regency. The track has controlled either residential area or non-residential area growth in suchway in purpose to make concentration of building construction lengthen in spatial distribution in stead of making it widen.

Concentric centrifugal spatial development at the fringe area of Makassar City is not iceable in aspect of urban area development form through out developed marginal area which had been cohesively unified. This condition takes place specifically at the central fringe area of Makassar City through an accumulation of activity. Center point of it is marked by the presence of shopping centers, and then followed by development of various other activities and supported by presence of
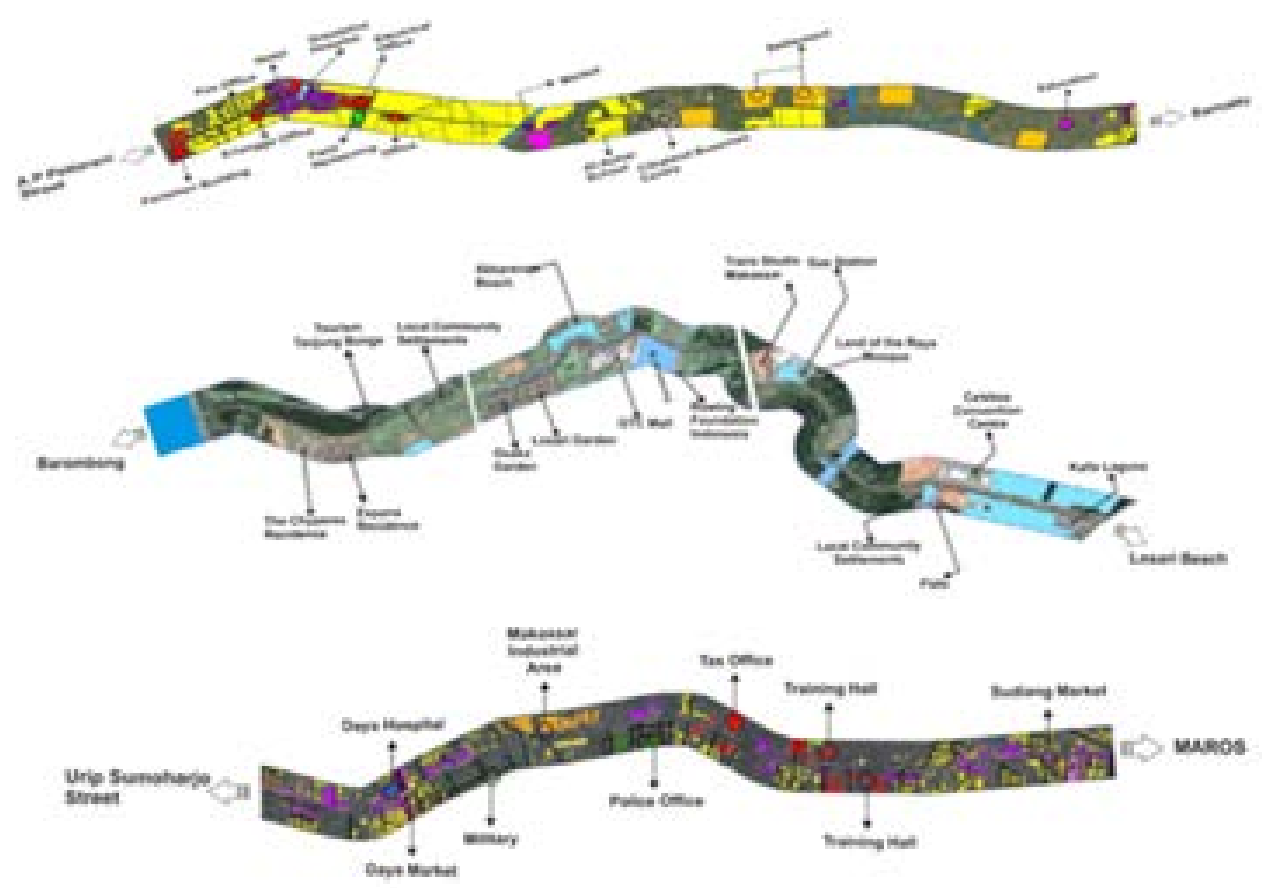

Figure 2. Linear Spatial Physical Development at the Urban Fringe Area of Makassar City 
residential area; those activities are cohesively unified. This process illustrates that the effort to control spatial physical form at the fringe area of Makassar City is much easier because outer land of the developed area is empty land, while minimal obstruction to reach this place allows the government to build urban open green space. Through out main road corridor from down town of Makassar City to the urban fringe has had various activities, for example: services, shopping complex, industry, high education, office complex, residential area and recreation (Figure 3).

Determinant of new spatial structure formation at the fringe area of Makassar City is dominantly affected by presence of main road corridor. It functions either to connect the fringe area and down town of Makassar or functions and changes travel pattern of residents in the fringe area from origin of place and to destination of movement. The main road corridors are (a) Metro Tanjung Bunga connecting Makassar City and Gowa Regency and Takalar Regency, (b) Urip SumoharjoPerintis Kemerdekaan connecting Makassar City and Maros Regency, and (c) Hertasning-Samata connecting Makassar City and Gowa Regency. In conformity with the fact found that these three main road corridors contribute positively to formation of service centers, and it affects significantly formation of spatial structure at the fringe area of Makassar City in addition to its contribution to the changes of resident mobility.

Table 3, spatial structure and spatial pattern changes at the fringe area of Makassar City in crease movement flow of resident and differentiate kinds of mode of transport tutilized by residents. Mode of transport used by inter resident also indicates significant difference. Use of transport mode types is highly determined by orientation of residentactivity. Utilized kinds of transport mode are motor cycle to support resident's business,for example hired motorcycle driver, green vegetable peddler, and construction worker. Bike is also used to work and sell goods from door to door. Movement to outside of this area is commonly carried out by public transportation.

Based on kinds of mode of transport utilized by most of migrants is private vehicle. Thus, it can be concluded that mode of transport used by inter resident to support their daily life indicates disparity between properties and vehicle ownership. Thus, means of production shift into reproduction of space indicating dynamics of spatial structure and spatial pattern changes at the fringe area of Makassar City shows movement differences in aspects of intensity, type of movement or
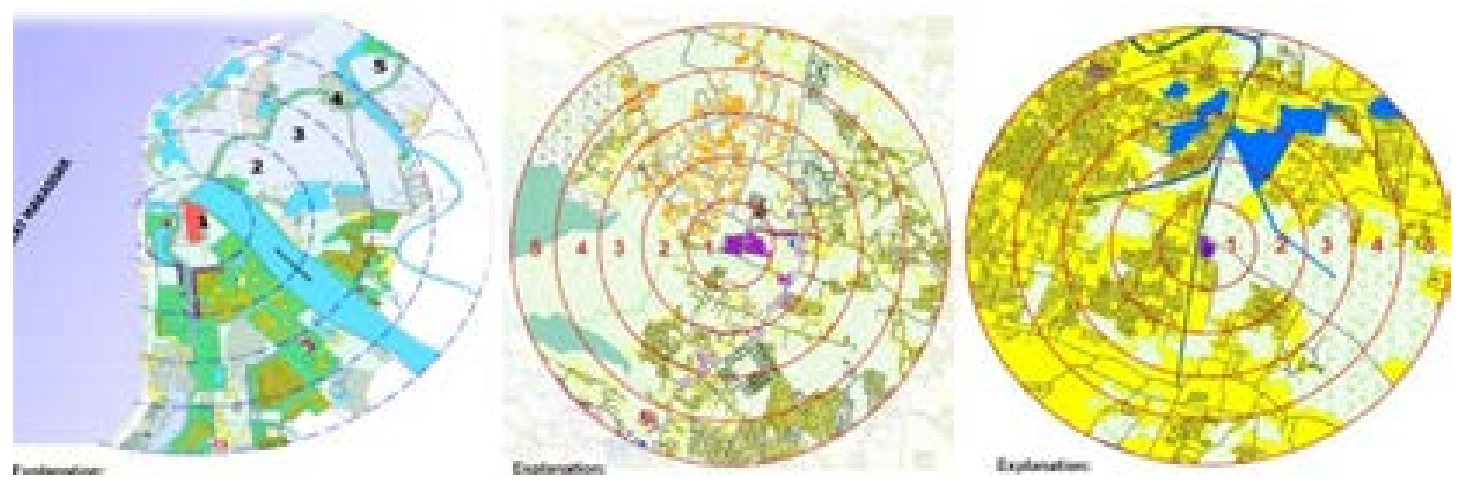

Figure 3. Concentric Spatial Physical Development at the Urban Fringe Area of Makassar City

Table 3. Comparison between Spatial Structure and Spatial Pattern Characteristics at Fringe Area of Makassar City, year period of 2000-2013

\begin{tabular}{lll}
\hline Description & \multicolumn{2}{c}{ Characteristics Change } \\
\cline { 2 - 3 } Pattern Space & $\begin{array}{l}\text { Physical Spatial Lama (1994-2000) } \\
\text { Dominated by agricultural land use } \\
\text { and farming Characterized by rural } \\
\text { agricultural }\end{array}$ & $\begin{array}{l}\text { Based on the functions(commercial, tourist,ser- } \\
\text { vice,office, and residential. }\end{array}$ \\
Structure Space & $\begin{array}{l}\text { Production activities directlyrelated to } \\
\text { the local community residential facilities } \\
\text { and traditional market activity }\end{array}$ & $\begin{array}{l}\text { Characterized by thecomplexity of urban } \\
\text { Linkage space transportation infrastructure is } \\
\text { supported withequipment and facilities ade- } \\
\text { quate support } \\
\text { Type of modern architectural design of luxury } \\
\text { to very luxurious }\end{array}$ \\
\hline
\end{tabular}


utilized mode of transport. This phenomenon affirms wealth gap between resident in and out of the fringe area of Makassar City [Surya, B. 2010].

Table 4, kinds of resident activity have an effect on space partitioning at the fringe area of Makassar City based on the existing spatial function. Based on grouping and categorization to the existing activities, changes of transport characteristics are directly affected by the following activities: trade/commercial, tourism/ recreation, and office. Thus, it can be concluded that changes of transport characteristics at the fringe area of Makassar City associate positively with primary functions of the area as an important part as the consequence of spatial structure and spatial pattern changes at this area.

Land use pattern which is divided based on spatial function will form travel profile, travel type and travel classification. This travel profile will depict changes of transport characteristics at the fringe area of Makassar City. It is not only affected by resident travel internally, but also affected by external factor from transport movement at the down town of Makassar City. Presence of main road corridor connecting the fringe area and down town becomes determinant of spatial utilization changes and transport characteristics changes at the fringe area of Makassar City. On the basis of observed travel pattern classification, the very high movement intensity is caused by origin of place and destination of movement from and to office complex, center of education and tourist resort or recreation area. (Table $5)$.

Based on the discussion above, it can be concluded that the emergence of new functions at the fringe area of Makassar City is starter of travel pattern changes performed by the residents. This travel pattern will always associate with changes of accessibility degree. One of factors supporting changes of accessibility degree at the fringe area of Makassar City is availability of the existing road network infrastructure. Difference of accessibility degree from residential area existing at

Table 4.Travel Patterns Matrix of Residents based on the Use of Mode of Transport at the Fringe Area of Makassar City

\begin{tabular}{lrrrrrr}
\hline \multirow{2}{*}{ Type Moda } & \multicolumn{7}{c}{ Category Population } \\
\cline { 2 - 7 } & Local & \multicolumn{1}{c}{$\%$} & New comers & \multicolumn{1}{c}{$\%$} & Total & \multicolumn{1}{c}{$\%$} \\
\hline Private Car & 5 & 1,87 & 214 & 53,23 & 219 & 32,74 \\
Public Transport & 56 & 20,97 & 83 & 20,65 & 139 & 20,78 \\
Motorcycles & 80 & 29,96 & 101 & 25,12 & 181 & 27,06 \\
Bicycles & 68 & 25,47 & 0 & 0,00 & 68 & 10,16 \\
Walking & 58 & 21,72 & 4 & 1,00 & 62 & 9,27 \\
Total & 267 & 100,00 & 402 & 100,00 & 669 & 100,00 \\
\hline
\end{tabular}

Table 5.Travel Pattern of Residents based on Activity Zone at the Fringe Area of Makassar City

\begin{tabular}{|c|c|}
\hline Activity & Classification (Profile) Journey \\
\hline $\begin{array}{l}\text { Economic Activity } \\
\text { 1.Production Business } \\
\text { 2.Consumption } \\
\text { 3.Trading }\end{array}$ & $\begin{array}{l}\text {-To and from business production } \\
\text {-To and from other workplaces } \\
\text {-To and from the shopping center (Mall) } \\
\text {-To and from market } \\
\text {-To and from the shopping center } \\
\text {-To and from market } \\
\text {-To and from the shopping center (Mall) }\end{array}$ \\
\hline $\begin{array}{l}\text { Social activity } \\
\text { 1.Family Relations (Patterns of SocialRelations) } \\
\text { 2.Education } \\
\text { 3.Religion } \\
\text { 4.Health } \\
\text { 5.Government } \\
\text { 6.Recreation }\end{array}$ & $\begin{array}{l}\text {-To and from the home of relatives } \\
\text {-To and from activities meeting } \\
\text {-To and from school (Campus) } \\
\text {-To and from other educational complex } \\
\text {-To and from the place of worship } \\
\text {-To and from hospitals or other treatmentcenters } \\
\text {-To and from office complexes } \\
\text {-To and from tourism / recreation }\end{array}$ \\
\hline $\begin{array}{l}\text { Activity Land Use } \\
\text { Added Population, Urbanization,Zoning-Zoning and } \\
\text { PhysicalDevelopment Zone periphery }\end{array}$ & $\begin{array}{l}\text {-To and from regional centers and CBD } \\
\text {-To and from the central services } \\
\text {-To and from Hospitality } \\
\text {-To and from the location of agricultureandfisheries } \\
\text {-To and from the location of settlements }\end{array}$ \\
\hline
\end{tabular}

Source: Primary data output, 2013 
the fringe area of Makassar City considers variables of time, cost, and choice of utilized mode of transport to service centers. By taking the valuated variables into consideration, it can be concluded that movement pattern from elite residential area to the existing service centers has high accessibility degree, if it is compared to residential area in habited by local residents. Difference of this accessibility degree will directly make differences based on the utilized transport means and infrastructure services.Concept of urban development developed by Bunge (in Yunus: 2008) on development pattern at residential area shows indication of inter-zones exist therein. Bunge divides space into three spatial zones, they area (1) innermost zone (the city of death), (2) zone of transition between (1) and (2) (the city of need), and outer most zone (the city of superfluity).

Based on the Figure 4, it explains that the in nermost zone is in habited by low in comeresidents for which it is marked by fewer social services. Residents living in this zone are exploited in such way by residents of other zone in form of "work exploitation". Zone of transition between zone 1 and 3 is part of the city inhabited by working class. Life of the residents here in is better than zone 1, but it is less than the outermost zone. The outermost zone is in habited by elite class having power, great professionalism; they are come from reliable business men to reliable politician. Residence of this class is classified as wonderful to "luxurious". If this approach is adapted to spatial context in macro perspective, it is relevant to beapplied. How ever, if it is adapted to micro-scale in urban area, specifically to the fringe area of Makassar City, it is conversely proportional to the reality.

Three spatial zones had been formed in development process of the fringe area of Makassar. The first cone known as main zone is inhabited by high socio economic class which associates with high income. This zone is shown by fully equipped social services, and it is close by activity centers (shopping center). Dominant residents living here inare migrants consisting of ruling elite group, highly professional, "business men". Zone of transition between zone 1 and 3 is location inhabited by working class; they aremigrants who come and live amongst native people. These residents consist of employee working in commercial economic activity and industry whose income is muchbetter than residents of zone 3. The outermost zone (zone 3) is in habited by local residents with low socioe conomic stratum. Residence of this class is, commonly, in formof raised platform and very plain, and it tends to seem like slum residential area.

Theoretical conceptualization of Marxist, developed by Harvey [2009], states that land allocation in the city is given to individual based on personal income. Further, land property will determine amount of rent and this variance amount of rent will create certain land use structure. Based on this perspective, it depicts that process of spatial structure and spatial

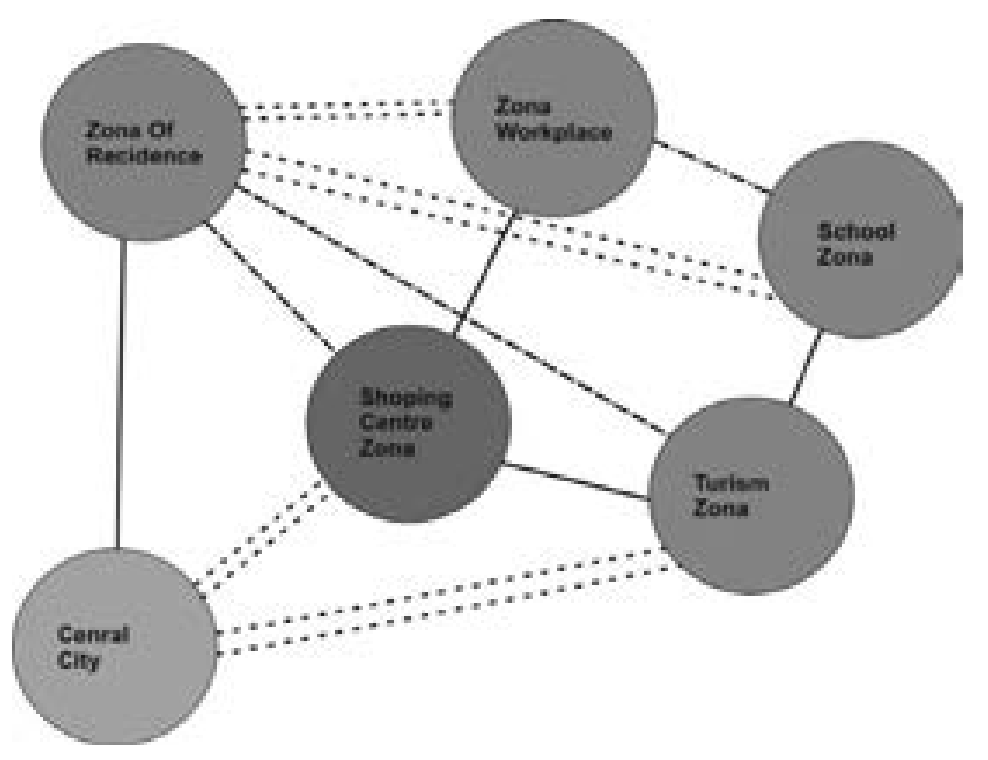

Figure 4. Different Inter-zone Travel Pattern at Fringe Area of Makassar City

Information:
a. : : : : $::=$ Very high travel volume
b. $-----=$ High travel volume
c. $-\cdot \cdot \cdot \cdot \cdot \cdot \cdot \boldsymbol{-}=$ Intermediate travel volume
d. = Low travel volume 
pattern changes at the fringe area of Makassar City has indication of domination over the existing land either to be used or to be utilized as the consequence of capital power. The refore, it can be concluded that land tenure occurredrecently is highly determined by individual fund ability and institution as the consequence of increasing land rental variance. It implies that the closer place by service centers, value of land is higher, and conversely.

Production of space at the urban fringe of Makassar City, basically, repositions role of land economic value which is no longer based on land potential as means of production, but reproduction of space. Reality found in the field indicates that spatial structure and spatial pattern changes at the fringe area of Makassar City has significant influence on land use value and land sales value/exchange rate. Use value is value of commodity in process of economy, while sales-value is value of commodity if it is sold. Based on development tendency of land use, influence of this process is that land use is no longervalued on productivity, but function of the land.

\section{References}

Denzin and Lincoln (2009), Hand Book Of Qualitative Research. Penerbit. Pustaka Pelajar Evers, HansDieter. 1974. Social Structure of Southeast Asian Cities: Case of Padang. Prisma Publisher.

Forbes, K.D. (1983), Geografi Keterbelakang (terjemahan oleh: A. Setiawan Abadi.Judul Asli: Geografhy of under-development). Penerbit LP3ES.

Harvey, D. (2009), Neoliberalisme Dan Restorasi Kelas Kapitalis. Penerbit. Resist Book.

Nas, P. J.M. (2005), Kota-Kota Indonesia (terjemahan oleh : Nin Bakdi Soemanto). Penerbit. Gajah Mada University Press.

Ritzer, G. (2008). Teori Sosiologi: Dari Teori Sosiologi Klasik Sampai Perkembangan Mutakhir Teori

\section{Conclusion}

Spatial utilization shift promotes intensive land use conversion. This phenomenon expands to morphological changes at the fringe area, causes complex spatial expression and makes framework of dominance over reproduction of space happen. This process will finally divide space at the fringe area of Makassar City into functions, although initial land use at this area was dominated by productive agricultural land.

Dynamics of spatial structure changes contribute to social structure changes. Social structure changes in the society indicate differences in livelihood orientation, social stratum, social status, and social class as the consequence of new spatial functions. The existing spatial function changes, then, expand to transport characteristics changes at the fringe area of Makassar City.

Dynamics of spatial pattern changes at the fringe area of Makassar City affect formation of spatial utilization zones. This production of space affects significantly land and space use value where tendency to utilize the space or land is no longer based on productivity, but the function.

Sosiologi Postmodern (terjemahan oleh: Nurhadi. Judul asli: Sociological Theory) Penerbit. Kreasi Wacana Yogyakarta.

Soetomo, S. (2009), Urbanisasi Dan Morfologi: Proses Perkembangan Peradaban dan Wajah Ruang Fisiknya. Penerbit. Graha Ilmu Yogyakarta.

Surya, B. (2010), Perubahan Sosial Pada Komunitas Lokal Kawasan Metro Tanjung Bunga Makassar, Laporan Hasil Penelitian Disertasi, Tidak Terpublikasi. Pasca Sarjana UNM.

Yunus, S.H. (2008), Dinamika Wilayah Peri-Urban Diterminan Masa Depan Kota. Penerbit. Pustaka Pelajar 